\title{
"I don't think I would be where I am right now". Pupil perspectives on using mobile devices for learning
}

Ros Walker*

United Learning and University of Huddersfield, UK

\begin{abstract}
Are pupils in the United Kingdom using mobile devices to help their learning? If so, what are they using and why? This article is based on research carried out by questionnaire, observation and pupil interviews at two English academies. One of the academies provides mobile devices for the pupils, and the other bans the use of mobile devices. The extent to which pupils are using their mobile devices to help their learning and which features they find useful for their schoolwork were examined. Pupils were also asked about some of the common barriers to using a mobile device in school: bullying, cheating and disruption. Results show that pupils at both schools do use their mobile devices for learning, with significantly more use at the school which allows mobile devices. However, usage is also significant in the school which currently bans devices. Pupils use their mobile devices for a wide range of activities, and the way in which pupils use their devices raises important questions for schools considering the adoption of mobile technology for teaching and learning. This article argues that schools should be actively encouraging pupils to make use of mobile devices.
\end{abstract}

Keywords: mobile learning; pupil voice; mobile phones; e-safety; pupil engagement

\section{Introduction and rationale}

The use of mobile technologies in education is becoming more widespread with each year that passes. In "Mobile Learning" (2005, p. 1), Kukulska-Hulme and Traxler state that "we are beginning to see significant adoption of these technologies in further and higher education, in schools and the community, and in training and updating". Eight years have passed since that was written, and the uptake in higher education in the United Kingdom has been significant. However, the uptake in secondary education has been slow, with schools restricting or banning their use. As recently as May 2012, Sir Michael Wilshaw, the chief inspector of schools in England, was reported to have called for a restriction on pupils' use of mobile phones in schools (Clark 2012). However, Charlie Osborne reports on ZD Net (2012) that $63 \%$ of pupils in schools where mobiles are banned use them anyway. So, why are schools afraid? It would appear that there are three key areas of concern: disruption to lessons, cheating and inappropriate use. However, some leaders in secondary schools are now giving serious consideration to the potential of mobile devices for improving learning outcomes.

The aim of this research was to establish whether pupils in England use their mobile devices for learning. It provides a snapshot in time of the way pupils viewed

\footnotetext{
*Email: roswalker@me.com

RLT 2013. (C) 2013 R. Walker. Research in Learning Technology is the journal of the Association for Learning Technology (ALT), a UK-based professional and scholarly society and membership organisation. ALT is registered charity number 1063519. http:// www.alt.ac.uk/. This is an Open Access article distributed under the terms of the Creative Commons Attribution 3.0 Unported (CC BY 3.0) Licence (http://creativecommons.org/licenses/by/3.0/) permitting use, reuse, distribution and transmission, and reproduction in any medium, provided the original work is properly cited. 


\section{R. Walker}

their mobile devices at two contrasting schools. The first school is typical of many across England. Pupils are allowed mobile phones in school providing they are kept out of sight and switched to "silent". Teachers do not encourage pupils to use their devices for learning. The second school in the study could be described as an "early adopter" school. The senior management has agreed to supply pupils with a device (iPod Touch), specifically for the purpose of improving learning outcomes. This initiative has been accompanied by significant curriculum and organisational changes.

The study aims to answer the following questions:

(1) Do pupils use mobile devices to help their learning?

(2) Which affordances of mobile devices are most useful to pupils?

(3) Do pupils think mobile devices help with their learning?

(4) Do pupils think mobile devices should be allowed in the classroom and on what basis do they make this judgement?

The study focused on pupils aged 14-16, chosen because these pupils are in key examination years, when pupils should be adopting a serious approach to their studies. Learning to research and study independently are key factors in examination success at this stage. However, the pupils are still legally classed as "children".

The converging affordances of mobile devices mean that pupils have access to a wide range of tools which could potentially assist their school work. Typically, a mobile device will now have a telephone, Internet connectivity, a camera, email, SMS, a calendar, a notepad, audio, video, a clock with alarm and an address book. Most smartphones also incorporate "apps" (applications or small programmes with varying functionality), which potentially extend hugely the functionality of the device as they can be used for a wide variety of purposes, dependent on the user's needs and interests. Each of these functions can be mapped to a potential benefit. For example, using email and SMS to connect with other students for discussion of work. Alom Shoha, writing in "The Independent" blog in 2011, suggests that schools do not need to ban mobile phones. He thinks that teachers should actually encourage the use of the cost-effective "mini computers" which pupils can use for a variety of purposes and which "can allow us to make the most of modern information technology in our classrooms".

The Apple Education case study on Normanby School states: "We need to keep listening to the children. Their voice was powerful in leading us to the iPod touch, and we must make sure we are always ready to use the best tools available to give children the best learning opportunities they can have". Above all, this research aims to "listen to the children".

\section{How do pupils use mobile devices?}

Writing in 2007, Kukulska-Hulme and Traxler point out that simply looking at the devices is "constraining and technocentric". The key thing to examine is "the underlying learner experience and ... how mobile learning differs from other forms of education" (Kukulska-Hulme and Traxler 2007, p. 181). Whilst there have been some studies on the way older students use devices in further and higher education, until recently studies within the UK secondary school context have been very limited. This is probably because few schools have taken the step of allowing devices. Towards the end of 2012, new research began to emerge on the ways in which 
devices are being used in schools. The "Tablets for Schools" project published some initial findings online from a study of "Children's Perceptions of One-to-One Tablets" with the following key results:

- "greater motivation to learn"; "more fun"; "creative"; "variety"

- "collaborative"; "feedback from their teacher"

- "classroom environment has improved"

- "improvements to communication"; "closer to their teachers"; "friends are supportive" (Tablets for Schools 2012).

There are also numerous, emerging personal accounts on the Internet about schools allowing pupils to use mobile devices. For example, Paul Haigh is quoted in an online article by Cole (2009) as: "Pupils are using a whole range of devices that can be used on the Internet - mobile phones, gaming devices, MP3 players. There's a huge untapped resource staring us in the face".

Perhaps, the most prevalent example of the way pupils use mobile devices is for Internet access at any time and in any place. Kukulska-Hulme and Traxler (2005, p. 31) note that "many mobile devices, unlike their desktop counterparts, are either 'always-on' or can be turned on instantly and can consequently respond quickly to learners' impulses". Wherever pupils are, whether at school, at home or in another location, they would be able to able to access the Internet.

Another area noted is connectivity through phone, SMS and social networking. Pupils can connect with teachers, other pupils or subject experts to enhance their engagement and understanding of a topic.

The multimedia capabilities of mobile phones are also worthy of consideration. Numerous websites suggest that pupils use their cameras, listen to MP3s or watch downloaded videos. A webpage about Normanby School on Apple's website mentions how "children make their own videos and capture images to present their work" (Apple, n.d.). However, there is little good evidence that this is either happening or improving learning.

Finally, the most recent arrival to the mobile learning environment is the "app". Pupils can download and use small programmes on their mobile devices. Again, the Internet is full of lists of "useful apps for learning", but there is very little evidence about whether pupils are using them for learning or how they are learning with them.

\section{Barriers to adoption of mobile learning in secondary schools}

Secondary education, whilst technology-rich in many ways, has been slower to adopt to mobile learning than higher education. The UNESCO report on mobile learning in Europe (2012) states that one barrier to mobile learning is "negative social attitudes that see mobile phones as disruptive devices".

Sharples in his article "Disruptive Devices" (2003) states that "A dilemma at the heart of networked learning is that learners can command an increasingly sophisticated set of communication and computing devices, which they are forbidden to use within formal education because they disrupt lessons and lectures". However, from schools that have adopted mobile technology a different viewpoint emerges. Liz Kolb, in Cell Phones in the Classroom (2011), writes that "teachers told me that they did not have any discipline problems when using the students' cell phones. 


\section{R. Walker}

Indeed, many of the teachers claimed that using cell phones for learning actually cut down on discipline problems in school related to cell phone use".

The discussion over cheating comes from differing perspectives on what we are teaching and why we are teaching it. Many adults grew up with a behaviourist approach to teaching in the classroom. Learning facts and being able to recall them correctly were paramount. In this respect, mobile technologies can help pupils to cheat. Lisa Nielsen (2008) explains this clearly in her blog "The Innovative Educator". She goes on to discuss how we "need to begin engaging in 'know where' (to find it) rather than 'know what' (the answer is) teaching" and how this can lead to more meaningful learning.

Susan Brooks-Young (2010, p. 28) writes about how teachers can "redesign activities and testing situations that currently make it all too easy for pupils to cheat". Quinn (2012, p. 63-64) reinforces this with a similar approach: "The issue is the balance between the knowledge that learners need to know and the application of that knowledge to solve problems. It is easy to test the former and typically harder to assess the latter".

One of aspects which most concerns schools is the issue of cyberbullying. Susan Brooks-Young (2010, p. 17) gives examples of some possible abuses. Cases where pupils have been bullied using the Internet and text messaging have been widely publicised and many schools have been confused about their approach to this form of bullying. Whilst it is clearly wrong to abuse a child in any way, much of it has been happening outside school hours using technology from home. If schools allow mobile devices and the abuse happens during lessons, the school could be held responsible for allowing the abuse to take place. The study will include questioning relating to cyberbullying and access to inappropriate material.

Headlines in the popular press do not paint a pretty picture. Within more academic literature there are also concerns: "Students are currently experiencing the majority of cyber bullying instances outside of the school day; however there is some impact at school" (Agatston, Kowalski, and Limber 2007, p. S59). Since 2007 the ownership of Internet-enabled mobile devices has increased dramatically. It has not been possible to find actual statistics for the number of pupils who have smartphones, but anecdotally it is now about $50-70 \%$ of pupils. This increase goes hand-in-hand with use of social networking sites. Charlie Osborne (2012) shows an infographic which claims that " $73 \%$ of wired American teens aged 12-17 use social networking sites". However, there is a strong counter-argument that mobiles need not pose a serious risk. Tanya Byron, in her report Safer Children in a Digital World (2008, p. 2) writes

Having considered the evidence I believe we need to move from a discussion about the media 'causing' harm to one which focuses on children and young people, what they bring to technology and how we can use our understanding of how they develop to empower them to manage risks and make the digital world safer.

Taking up Byron's theme of empowerment, this article focuses on the voice of the pupils themselves and their feelings towards the technology.

\section{Plan and methodology}

There are difficulties in carrying out this type of research, highlighted by Mark Kramer writing in Vavoula, Pachler, and Kukulska-Hulme (2009, p. 182). He highlights the fact that devices are personal and used in a wide variety of locations, so it is difficult to find out exactly which interactions do take place. 
The research uses a model proposed by Wali, Oliver, and Winters, in their article "Are They Doing What They Think They're Doing? Tracking and Triangulating Students' Learning Activities and Self Reports" (Vavoula, Pachler, and Kukulska-Hulme 2009, p. 317-335) (Figure 1).

The data for this study were drawn initially from a questionnaire, which was developed from criteria within the literature review and wider reading. Due to the size of the group (up to 400 students), the questionnaire consisted mainly of closed questions with a few options for free entry. This allowed for quantitative data analysis and some degree of comparison between the two academies. The questionnaire was completed electronically using Survey Monkey to facilitate the administration for the schools and the analysis of data.

The second stage involved carrying out some school observations. These were only carried out at the school where devices can legitimately be used during lesson time. The observations were important to triangulate the pupil data and "to reveal characteristics of groups or individuals which would have been impossible to discover by other means" (Bell 1993, p. 109).

In the third stage, four pupils at each school kept a diary for 24 hours, recording all their mobile device use. This was primarily to research what they were doing with their devices at home to validate pupil data from the questionnaires. It also gave a more detailed insight into the times, places and applications which pupils use on their mobile devices.

The final stage also took place in both schools. Four pupils, selected by management at the school, were interviewed in a semi-structured interview, based on the data from their 24-hour study, the lesson observations and the data from the initial questionnaire. The interviews were video recorded and later transcribed and tagged to allow for thematic analysis.

\section{The findings}

A total of 325 questionnaires were completed. Of these, 248 were completed by pupils at the Academy which does not allow mobile devices (Academy A) where pupils completed them in lesson time. Forty-seven were completed at the Academy which does allow mobile devices (Academy M) where students were emailed the link and left to complete it in their own time.

Step 1: Collect student
self reports at the
beginning of the study.
Step 2: Collect real-wo
and more descriptive dat
about students' utilisati
of portables.
Step 3: Clarify issues
found in the collected
data.

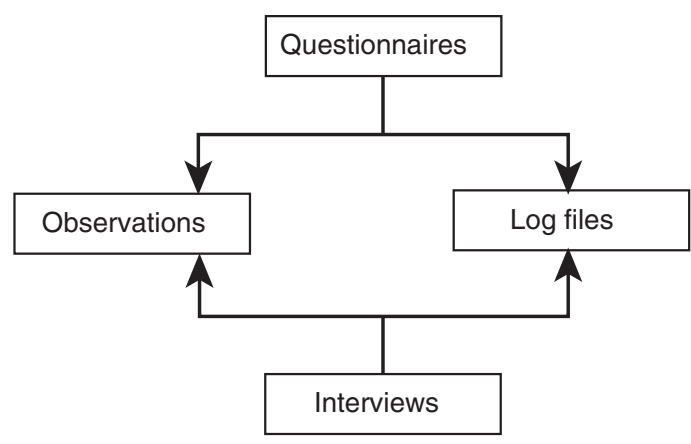

Figure 1. Research methods order in Vavoula, Pachler, and Kukulska-Hulme (2009). 


\section{R. Walker}

The first research question sought to establish whether pupils were using their mobile devices to help their learning (Figure 2).

The results showed that $74 \%$ of pupils at Academy M use mobile devices to help with learning, as opposed to only $43 \%$ of pupils at Academy A. The management of Academy $\mathrm{M}$ was surprised and slightly disappointed with the outcome of this question, given the investment made in the technology. However, the cohort questioned had grown up with a more traditional methodology and, during the observations, it was noted that the level of use of mobile devices amongst teachers was very varied. The school plans to use this data as a benchmark for further research. The result from Academy A was slightly higher than expected, given that no one had ever asked the pupils there to use their devices. This means that the pupils are using them with their own initiative.

It was interesting to examine the type of devices that the pupils were using. The graph in Figure 3 shows the ownership of devices. The pupils at Academy $\mathrm{M}$ almost all have an iPod Touch, given to them by the school. Theoretically, it should be $100 \%$ ownership, but the school says there are a number of pupils with broken or lost devices. The ownership of Smart Phones at Academy A was higher than had been expected. In interviews with pupils, it was surprising to find that many pupils now give serious consideration to their schoolwork when choosing a device:

Interviewer: So would you say your phone is more important to you for your schoolwork or for your home and social life?

Pupil: It's more important for school. Everything that I have on the phone, such as the calendar, only has school things on. (Academy A)

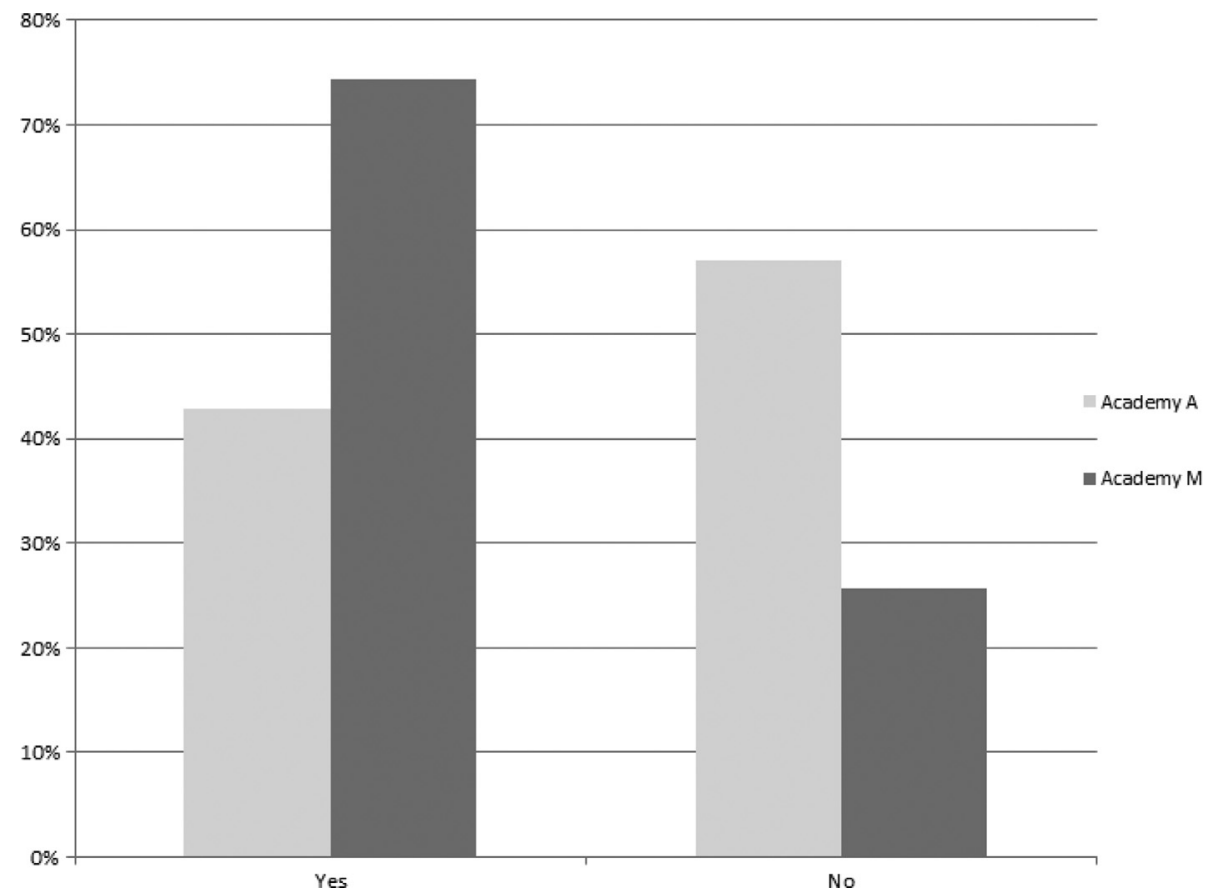

Figure 2. Do you use mobile devices to help you with your learning? 


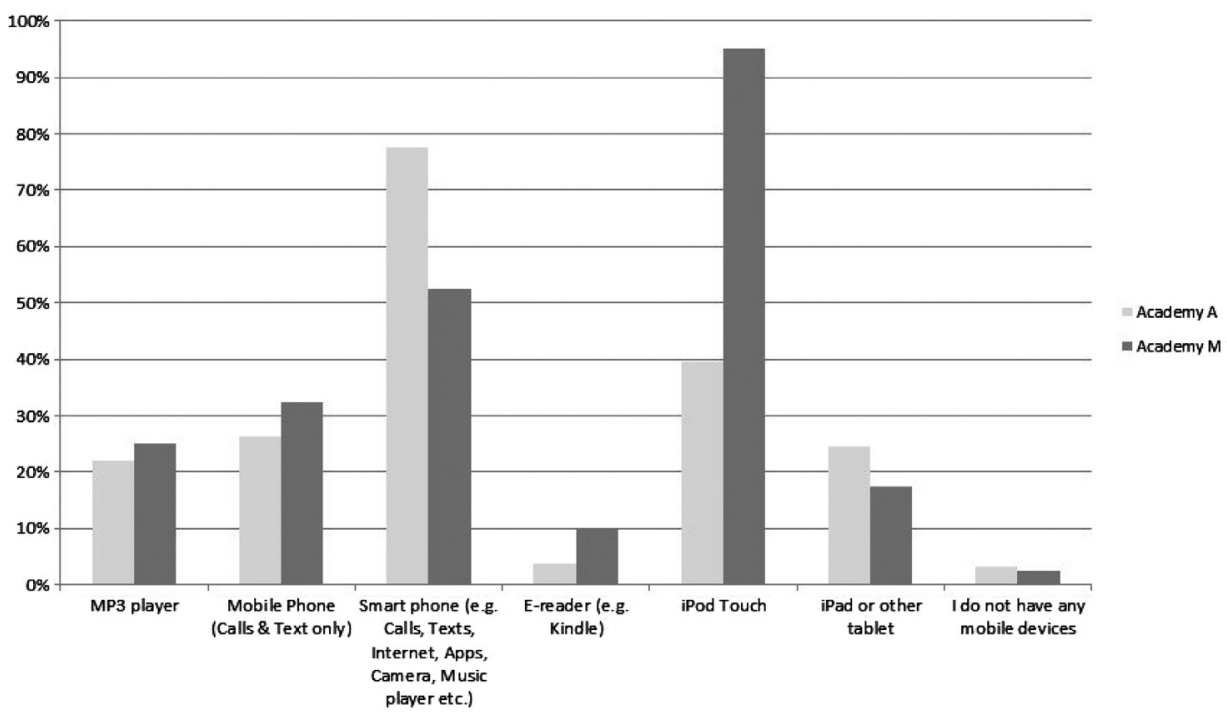

Figure 3. Which mobile devices do you own?

Having established the number of pupils using their mobile devices for learning, the next question examined the affordances used by pupils. Figure 4 shows the result, sorted in order of use by pupils at Academy M.

Based on the responses given, it has been possible to group the affordances of the mobile devices: the Internet, organisational tools, audio-visual tools, learning tools and communication tools. There are striking differences in the patterns of usage between the two schools.

Pupils at both schools see the Internet as the starting point for almost everything. One pupil remarked in interview "You can't go wrong with Google". On the

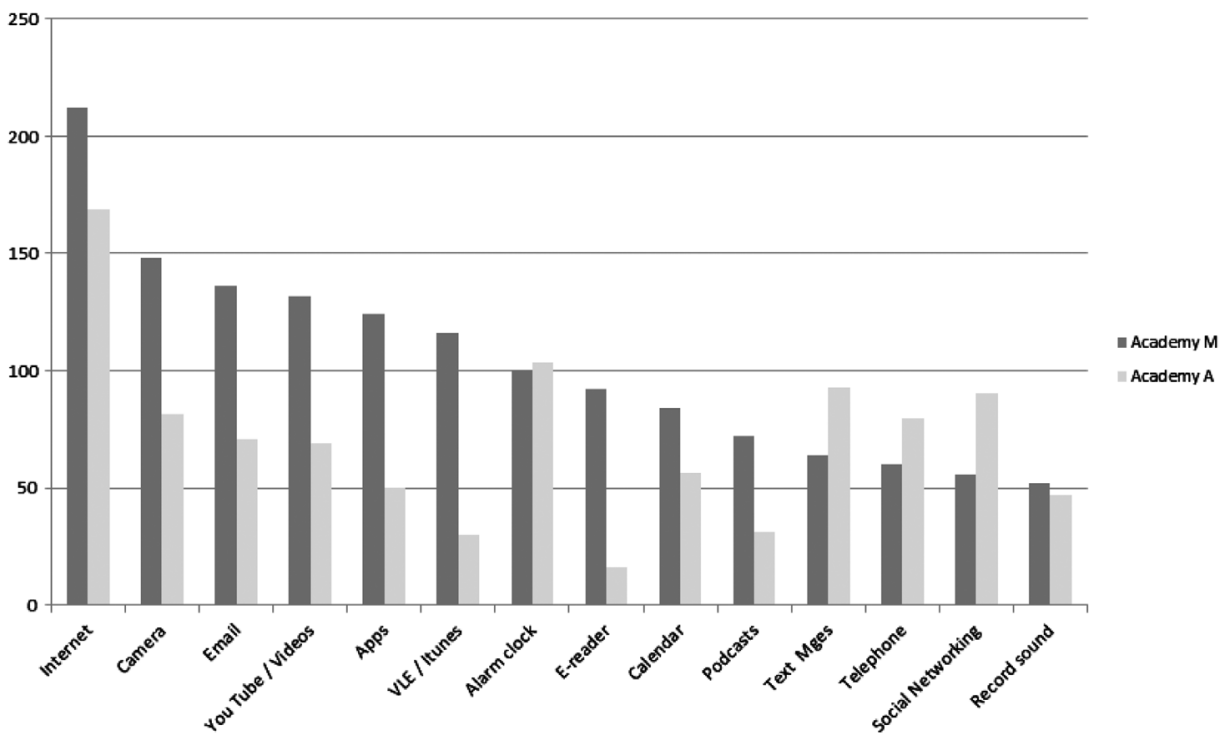

Figure 4. Usage of mobile device affordances for learning by pupils. 


\section{R. Walker}

questionnaires, pupils made many comments about the Internet, including: "if i didn't know the answer to something, i look it up on the internet" [sic], "when I need help and information", "research at home", "when I am stuck with something". This feature produced the largest response from pupils and highlighted the perceived omniscience of cyberspace for the young people.

Organisational tools were also important at both schools. This category included the calendar and alarm clock. It was striking to see how reliant the pupils were on the calendar functions. Whilst this may not be apparent from the questionnaire data, it was a point repeatedly mentioned in the interviews. One pupil said his device was essential for "remembering things" and without he would "forget to take homework in a lot". On being asked "What do you think are the best things about using your mobile device for learning?" Another pupil replied: "It's portable. That would be my main [point]. You can take it round.... You don't have to remember things, just put it into your mobile straightaway. But the problem is, you're not allowed it at school ... you can't get it out but you need to get it out to remember things". It is interesting to note from the observations that pupils at Academy M no longer have "planners". They keep their own records using their calendars and sometimes take photographs of homework instructions.

In the interviews, audio-visual tools, such the camera and sound player/recorder were discussed in much more detail. Several pupils expressed a preference for learning from video. One pupil discussed how he was highly attracted to a video format for his work: "It's just like, in my head, I don't like words. I like pictures and that's how I remember it in my head". He goes on to give an example where he remembered everything from a video shown in a Science lesson. This relates to Mayer's Cognitive Theory of multimedia learning by employing both auditory and visual channels for processing information.

In the mobile academy, the camera was also used a considerable amount - to take photographs of teacher's work on the board, to take photos of pupils' own work (such as Science experiments) and for creative purposes (e.g. Art lessons).

Pupils were questioned about their use of learning tools, which would be those affordances specifically designed to facilitate learning. iTunesU was widely used at Academy M, as the lesson frameworks were delivered using it. Apps also appeared to be popular at Academy M, but in the interviews it became clear that pupils were confused about what constituted an app. They were able to name generic "apps" such as "Keynote" and "Pages" but faltered when it came to naming any subject-specific apps.

In theory, pupils in Academy A have eight hours less per day in which to use the devices but they freely admitted that they did use them in their lessons, and often with the teacher's covert agreement. One pupil describes how he looked up some information because the teacher was busy with other pupils on his computer.

Communication tools were the area that saw the greatest variance between schools. Whilst all pupils interviewed said they did use some form of communication between themselves and with their teachers, it was the pupils at Academy A who made particular use of text messaging and social media. Some lived in rural areas and keeping in touch in the evening involved text messages or calls. One pupil described working with a friend on homework using a video call. "I like to do video calls because then that way I can show them what it is, cos sometimes I struggle to explain what it is .... A few days ago, my friend didn't understand one of the questions on the 
Science homework, so he Facetimed me, and I showed him my answer and I explained how I got that answer to him ...."

It is possible that cultural differences between the schools play a part in the difference between the way in which communication takes place. Academy A is in a semi-rural location and in interviews pupils mentioned that they often did not see their friends face-to-face in the evenings. Academy $M$ is in an urban setting with pupils often participating in community events during the evenings with friends and family, giving less need and less opportunity to use communication and social media tools. Pupils at Academy M do make great use of email, particularly for emailing their teachers. Teachers are available in the evenings and will "usually reply within twenty minutes" to emails from pupils.

Given the demonstrated use that pupils are making of their mobile devices, what is their perception of the usefulness of the device in helping with their learning? Figure 5 shows that pupils at both schools lean towards a belief that the mobile devices do help with their learning. Pupils were asked more specific questions about this in interview and one made the following statement:

Without this [showing iPad], I don't think I would be where I am right now, because it's helped me hugely with all my stuff. When we never used to have this, I'll be honest, I was on Grade D's. But now, cos I've got this, I'm on Grade A's and B's. It's a great opportunity.

This led to a more specific question about whether pupils should be allowed to use mobile devices during their lessons (Figure 6).

It is interesting that both schools gave almost the same result. In this question, pupils were able to give a reason for their answer and it became clear that the answer was not always based on learning. Against the suggestion, pupils said "Because most people are tempted to play games on it therefore not concentrating in lessons" (Academy M); "NO, because if we did have mobile phone in lessons, then we will be

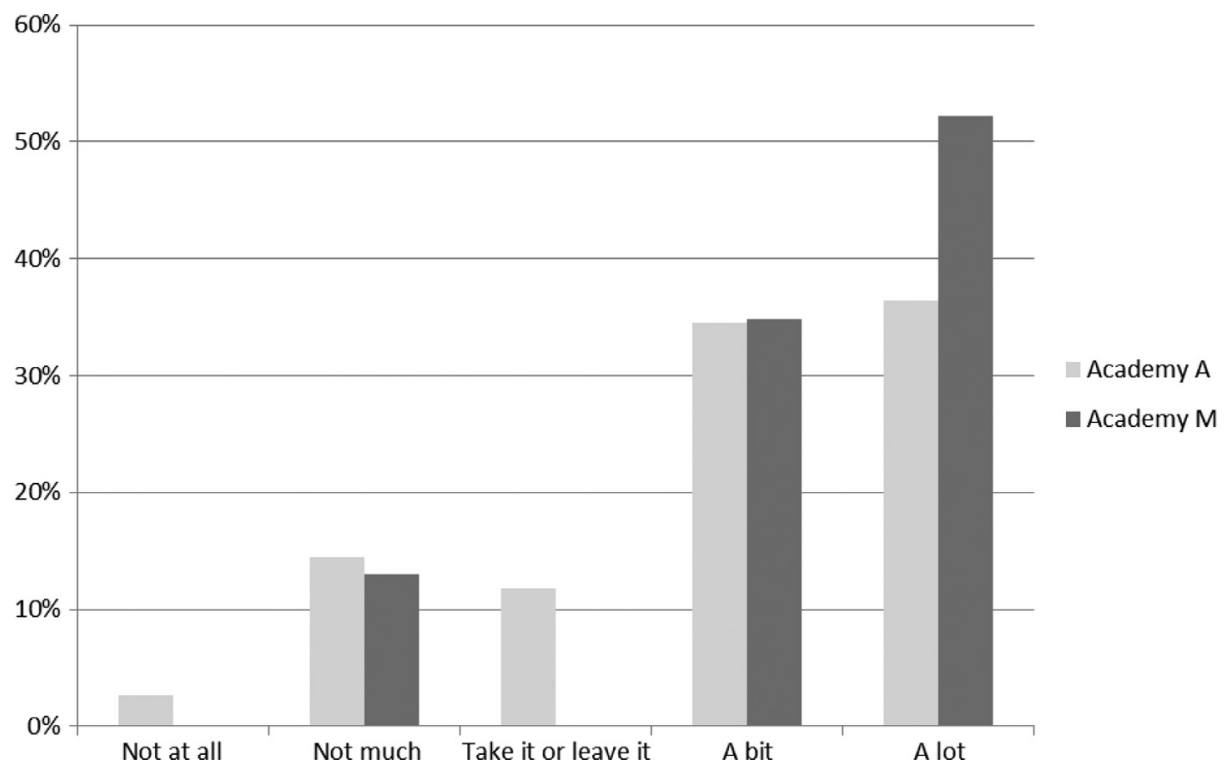

Figure 5. How much do you feel a mobile device helps your learning? 


\section{R. Walker}

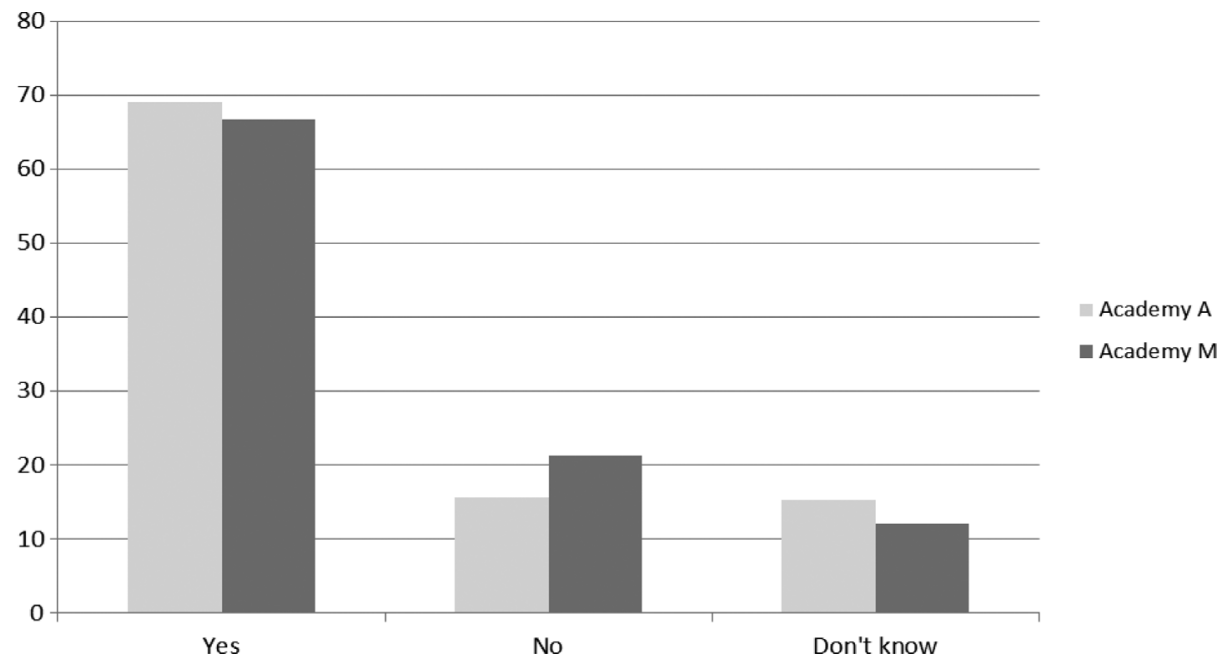

Figure 6. Do you think you should be allowed to use mobile devices in lessons?

texting in lesson not focusing on the lesson and then we will get low grades" (Academy A). In favour of the question were the comments "because it helps so much in lessons" (Academy M); "so then if the laptops are going slow we could use our phone for internet research" (Academy A); "so you can use the calculator on it" (Academy A); "cause I get bored and I wanna text my bird" (Academy A). Pupils clearly recognise the power of the device to distract - in a positive and a negative way. It would be up to the teacher to curb the distraction and this is pointed out by one pupil who admitted to getting distracted by his device:

Interviewer: Do you think that hurts your learning at all?

Pupil: Obviously, you do miss out but it's just the truth.

Interviewer: What advice do you think you would give to teachers about pupils being distracted in lessons?

Pupil: Just like - keep an eye on them. If the lesson's more enjoyable, the students won't actually have to go on the iPads to play games and use the iPads more frequently.

In terms of the other barriers to adoption mentioned in the literature, pupils had very little to say. Cheating was mentioned just once in a questionnaire and the pupil said "It's not cheating - it's helping yourself". This echoes the literature review standpoint about teachers setting creative tasks.

Bullying and inappropriate use of devices did raise some comments and as the data in Figure 7 show, it is something of a problem in both schools, although interestingly, less of a problem in the school that allows devices. This could be cultural and related to the close-knit community. One pupil at Academy $\mathrm{M}$ said "Why would we want to do bad stuff to our brothers and sisters?"

In the subsequent interviews, not one pupil felt that the threat of unpleasant behaviour was enough to put them off using their device for learning. One of the pupils had experienced cyberbullying but was still very resistant to the idea of giving up his device:

The cyberbullying is only a short-term thing, I think. When it's sorted, it's fine. It wasn't really a big problem to learning anyway because it was just some people who were being harsh .... It's because you go on Facebook and Twitter, they're really the only 


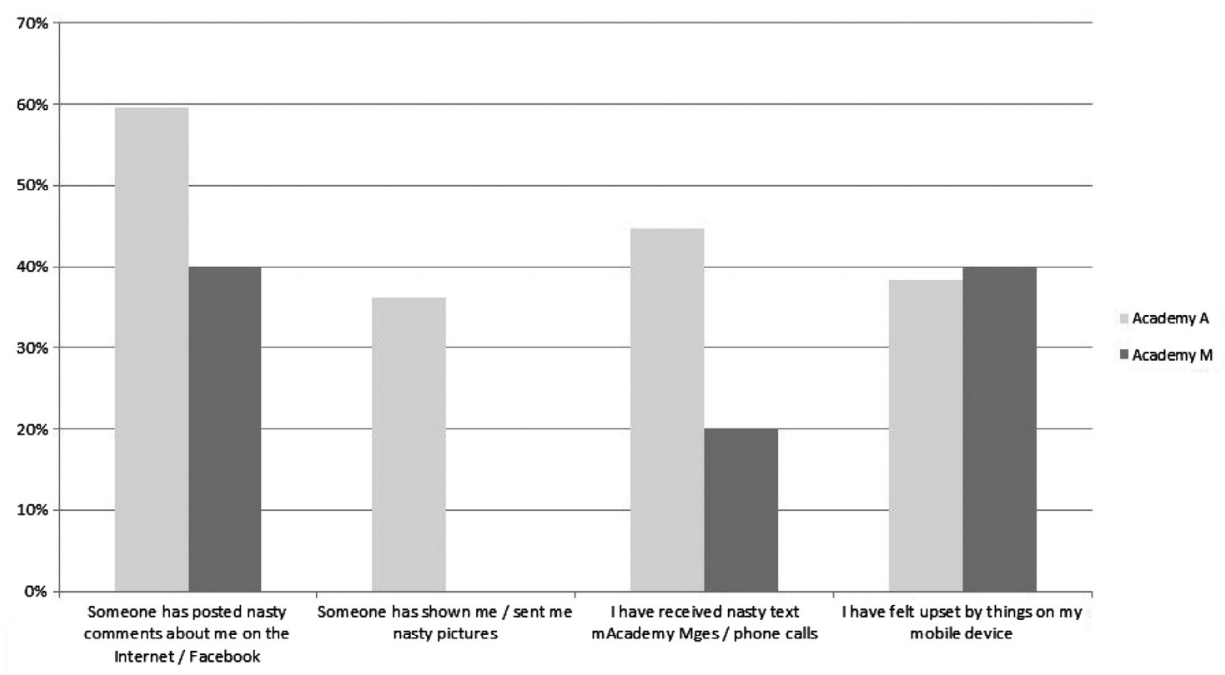

Figure 7. Have any of the following ever happened when using a mobile device?

places you do get bullied. But if you're just using your phone for purposes like in school for schoolwork, there's not much chance to get bullied. So it wouldn't be too big a problem.

Given the relatively high number of pupils who have experienced a problem, it is possible that the pupils selected for interview by the schools were those who felt more positive about the devices, so it may be more accurate to rely on the numbers in Figure 6 that suggest $70 \%$ of pupils would be happy to have the devices in class.

\section{Conclusion}

This article shows how much pupils are already using mobile devices - whether allowed by their school or not. There is clear evidence that many pupils feel that they are deriving educational benefit from the use of their devices. They are using many of the features of their devices and often finding creative ways to employ these features in their schoolwork, both at home and at school.

The findings raise questions for Secondary leadership and educators. In those schools which still impose a "ban", is it necessary? Are pupils confused by rules which ban mobile devices but where teachers do unofficially allow their use? Are there more creative ways of presenting the curriculum which would make use of the affordances of mobile devices?

During the time this research has taken place (August-December 2012), there have been significant changes in attitude to mobile devices. Many schools are now giving serious consideration to mobile learning, with some having already distributed one-one devices (Tablets for Schools 2012). This article shows that pupils themselves believe that mobile devices help with their learning and that they are convenient and useful. However, pupils also acknowledge their potential for disruption and for harm. Schools need to be fully aware of the risks and put in place measures to minimise any negative impact.

Further research should be undertaken to examine in more depth the pedagogical changes which are accompanying the use of devices inside and outside school. 


\section{R. Walker}

There is also a need for an examination of data showing whether the use of the devices does assist attainment.

\section{References}

Agatston, P., Kowalski, R. \& Limber, S. (2007) 'Students' perspectives on cyber bullying', Journal of Adolescent Health, vol. 41, no. 6 (Suppl 1), pp. S59-S60.

Apple. (n.d.) Apple in Education, Apple, [online] Available at: http://www.apple.com/uk/ education/profiles/normanby/

Bell, J. (1993) Doing Your Research Project, OUP, Buckingham.

Brooks-Young, S. (2010) Teaching with the Tools Kids Really Use, Corwin, CA.

Byron, T. (2008) Safer Children in a Digital World, Crown Copyright, Nottingham.

Clark, L. (2012). 'Ban mobiles from schools', Daily Mail, May 9, [online] Available at: http:// www.dailymail.co.uk/news/article-2142085/Ofsted-chief-gets-tough-classroom-disciplineschools-penalised-failing-tackle-disruption.html

Cole, G. (2009, Oct 2). 'Sheffield school pioneers mobile phones for learning, Agent4change. net' (Merlin John Online), Available at: http://www.agent4change.net/innovation/innovation/ 417-sheffield-school-pioneers-mobile-phones-for-learning.html

Kolb, L. (2011) Cell Phones in the Classroom: A Practical Guide for Educators, International Society for Technology in Education, Washington.

Kukulska-Hulme, A. \& Traxler, J. (2005) Mobile Learning: A Handbook for Educators and Trainers, Routledge, Abingdon.

Kukulska-Hulme, A. \& Traxler, J. (2007) 'Designing for mobile and wireless learning', in Rethinking Pedagogy for a Digital Age, eds H. Beetham \& R. Sharpe, Routledge, Abingdon, pp. 180-192.

Nielsen, L. (2008, 12 May). 'The value of using cell phones to enhance education and some concrete ways to do so', Available at: http://theinnovativeeducator.blogspot.co.uk/2008/05/ value-of-using-cell-phones-to-enhance.html

Osborne, C. (2012, 6 April). 'What do high school students want from mobile tech?' Available at: http://www.zdnet.com/blog/igeneration/what-do-high-school-students-want-from-mobiletech-infographic/15843

Quinn, C. (2012) The Mobile Academy, John Wiley \& Sons, San Francisco.

Sharples, M. (2003) 'Disruptive devices: mobile technology for conversational learning', International Journal of Continuing Engineering Education and Lifelong Learning, vol. 12 , no. $5 / 6$, pp. $504-520$.

Shoha, A. (2011, Nov 9). 'Don't ban mobiles in schools. Let students use them'. Available at: http://blogs.independent.co.uk/2011/11/09/don\%E2\%80\%99t-ban-mobile-phones-inschools-let-students-use-them-all-the-time/

Tablets for Schools. (2012, July). Key Findings, Stage 1. Retrieved February 24, 2013, from Tablets for Schools: http://www.tabletsforschools.co.uk/?page_id $=680$

UNESCO. (2012) Turning on Mobile Learning in Europe, UNESCO, Paris, France.

Vavoula, G., Pachler, N., \& Kukulska-Hulme, A. (2009) Researching Mobile Learning, Peter Lang, Bern. 